\title{
Homozygosity mapping in albinism patients using a novel panel of 13 STR markers inside the nonsyndromic OCA genes: introducing 5 novel mutations
}

\author{
Faravareh Khordadpoor-Deilamani ${ }^{1}$, Mohammad Taghi Akbari ${ }^{2,3}$, Morteza Karimipoor ${ }^{3,4}$ and \\ Gholam Reza Javadi ${ }^{1}$
}

\begin{abstract}
Albinism is a heterogeneous genetic disorder of melanin synthesis that results in hypopigmented hair, skin and eyes. It is associated with decreased visual acuity, nystagmus, strabismus and photophobia. Six genes are known to be involved in nonsyndromic oculocutaneous albinism (OCA). In this study, we aimed to find the disease causing mutations in albinism patients using homozygosity mapping. Twenty three unrelated patients with nonsyndromic OCA or autosomal recessive ocular albinism were recruited in this study. All of the patients' parents had consanguineous marriage and all were screened for TYR mutations previously. At first, we performed homozygosity mapping using fluorescently labeled primers to amplify a novel panel of 13 STR markers inside the OCA genes and then the screened loci in each family were studied using PCR and cycle sequencing methods. We found five mutations including three mutations in OCA2, one mutation in SLC45A2 and one mutation in C10ORF11 genes, all of which were novel. In cases where the disease causing mutations are identical by descent due to a common ancestor, these STR markers can enable us to screen for the responsible genes.
\end{abstract}

Journal of Human Genetics (2016) 61, 373-379; doi:10.1038/jhg.2015.167; published online 28 January 2016

\section{INTRODUCTION}

Albinism is a rare genetic disorder which affects $\sim 1$ in 20000 individuals worldwide, although the prevalence of the different subtypes of albinism varies considerably among different populations. Melanin production which occurs in melanocytes is closely regulated. Defects in the melanin biosynthesis or transport result in hypopigmentation. ${ }^{1-4}$

Oculocutaneous albinism (OCA) is a heterogeneous and autosomal recessive disorder with the symptoms of lack of pigment in the skin, hair and eyes, and optic defects such as photophobia, strabismus, poor vision and nystagmus. ${ }^{2,5,6}$

Mutations in HPS1, AP3B1, HPS3, HPS4, HPS5, HPS6, DTNBP1, BLOC1S3, BLOC1S6 (PLDN), LYST and genes result in syndromic OCA, while mutations in TYR (OMIM:606933), OCA2 (OMIM:611409), TYRP1 (OMIM:115501), and SLC45A2 (OMIM:606202), SLC24A5 (OMIM:609802) and C10ORF11 (OMIM:614537) genes cause nonsyndromic forms of this disease (OCA1, OCA2, OCA3, OCA4, OCA6 and OCA7, respectively). Also an OCA locus is mapped to $4 \mathrm{q} 24$ in a consanguineous Pakistani family, which may be responsible for OCA5 (OMIM:615312), but the gene has not been described. . $^{1,-10}$
OCA1A (tyrosinase-negative OCA) (OMIM:203100) is caused by TYR null mutations and melanin formation never occurs throughout the patient's life. In contrast, hair of individuals with OCA1B (OMIM:606952) in which mutations produce a partially active or hypomorphic tyrosinase enzyme turns to yellow or blonde with age. . $^{3,4,11}$

The OCA2 (OMIM:203200) patients have generally less severe clinical phenotype than OCA1 and most affected patients accumulate pigment with age. It is caused by mutations in the $P$ (OCA2) gene, which codes for a melanosomal membrane protein. $\mathrm{P}$ protein plays a role in regulating the $\mathrm{pH}$ of melanosomes and may be involved in the transport of tyrosine or some other small molecule into the melanosome. ${ }^{2,12}$

Mutations in TYRP1 gene cause OCA3 (OMIM:203290). TYRP1 has partial tyrosinase hydroxylase activity and catalyzes the oxidation of 5,6-dihydroxyindole-2- carboxylic acid in the melanin biosynthesis pathway. ${ }^{13,14}$

OCA4 (OMIM:606574) is due to mutations in SLC45A2 (MATP) that probably acts as a melanosomal protein and substance transporter. ${ }^{13,15}$

\footnotetext{
${ }^{1}$ Department of Biology, Science and Research Branch, Islamic Azad University, Tehran, Iran; ${ }^{2}$ Department of Medical Genetics, Faculty of Medical Sciences, Tarbiat Modares University, Tehran, Iran; ${ }^{3}$ Tehran Medical Genetics Laboratory, Tehran, Iran and ${ }^{4}$ Department of Molecular Medicine, Biotechnology Research Center, Pasteur Institute of Iran, Tehran, Iran

Correspondence: Dr MT Akbari, Department of Medical Genetics, Faculty of Medical Sciences, Tarbiat Modares University, P.O. Box: 14115-331, Tehran 02182884555, Iran. E-mail: mtakbari@modares.ac.ir

Received 8 October 2015; revised 16 November 2015; accepted 26 November 2015; published online 28 January 2016
} 
Table 1 Thirteen STR markers inside the oculocutaneous albinism (OCA) genes were selected for homozygosity mapping

\begin{tabular}{|c|c|c|c|c|c|c|}
\hline Gene/RefSeq & $\begin{array}{l}\text { STR markers and their probe } \\
\text { accession numbers }\end{array}$ & $\begin{array}{l}\text { STR location } \\
\text { inside the gene }\end{array}$ & $\begin{array}{l}\text { Consensus } \\
\text { sequence }\end{array}$ & Primer sequence & Size (bp) & $\begin{array}{c}\text { Fluorescent } \\
\text { label }\end{array}$ \\
\hline \multirow[t]{2}{*}{ TYR NG_008748.1 } & $\mathrm{S} 1=\operatorname{Pr032754300}$ & $\begin{array}{l}\text { Between exons } 2 \\
\text { and } 3\end{array}$ & TCTA & $\begin{array}{l}\text { F: 5'-AGTTGGCATCGTCGATGGTTAC-3' } \\
\text { R: 5'-GGTGTACCATGGGCAAATTCTG-3' }\end{array}$ & 262 & FAM \\
\hline & S2 $=$ Pr032754301 & $\begin{array}{l}\text { Between exons } 4 \\
\text { and } 5\end{array}$ & $A C$ & $\begin{array}{l}\text { F: 5'-TGCTTTTAGGAATTTTACAAACTGTTCA-3' } \\
\text { R: 5'-GCGTTTATCCTAAGGACCATTCTG-3' }\end{array}$ & 351 & FAM \\
\hline $\begin{array}{l}\text { OCA2 (P) } \\
N G \_009846.1\end{array}$ & S1 $=$ Pr032754296 & $\begin{array}{l}\text { Between exons } 2 \\
\text { and } 3\end{array}$ & TG & $\begin{array}{l}\text { F: 5'-GTTGATTTATGTAACATTCCTGCTGG-3' } \\
\text { R: 5'-GAGGTTACATAAAGCTACCCAAGTGA-3' }\end{array}$ & 109 & FAM \\
\hline \multirow[t]{2}{*}{$\begin{array}{l}\text { TYRP1 } \\
\text { NG_011705.1 }\end{array}$} & $\mathrm{S} 1=\mathrm{PrO} 32754302$ & Before exon 1 & TG & $\begin{array}{l}\text { F: 5'-ACGTTCCAGAGTAAGTAGCATATGGT-3' } \\
\text { R: 5'-GAGATGTGTGGCACTGGATGGA-3' }\end{array}$ & 456 & HEX \\
\hline & $\mathrm{S} 2=\mathrm{Pr032754303}$ & $\begin{array}{l}\text { Between exons } 5 \\
\text { and } 6\end{array}$ & TG & $\begin{array}{l}\text { F: 5'-ACAATTCCCTGATCTCAACCCTC-3' } \\
\text { R: 5'-GCTTAAGTTGCCAGATGTTACTTCAG-3' }\end{array}$ & 384 & HEX \\
\hline $\begin{array}{l}\text { MATP } \\
\text { NG_011691.1 }\end{array}$ & $\mathrm{S} 1=\mathrm{PrO} 32754294$ & $\begin{array}{l}\text { Between exons } 2 \\
\text { and } 3\end{array}$ & TG & $\begin{array}{l}\text { F: 5'-AACCAATGGGGAAGATATAAGAAGAGT-3' } \\
\text { R: 5'-GTCTTGTAGAAGGTTAACCAGGTTCA-3' }\end{array}$ & 153 & FAM \\
\hline \multirow[t]{2}{*}{$\begin{array}{l}\text { SLC24A5 } \\
N G \_011500.1\end{array}$} & $\mathrm{~S} 1=\operatorname{PrO} 32754298$ & Before exon 1 & TG & $\begin{array}{l}\text { F: 5'-TGGTATGAAAGAAAGGGGACACAG-3' } \\
\text { R: 5'-CAACTGGGTTGGTCATCGTTTC-3' }\end{array}$ & 224 & HEX \\
\hline & S2 $=$ Pr032754299 & Before exon 1 & GAAA & $\begin{array}{l}\text { F: 5'-AAGCAACTTACTCCGTTCCATCAG-3' } \\
\text { R: 5'-CGACCTCTGGCTGACGTCTTC-3' }\end{array}$ & 408 & FAM \\
\hline \multirow[t]{3}{*}{$\begin{array}{l}\text { C100RF11 } \\
\text { NG_042180.1 }\end{array}$} & $\mathrm{S} 1=\mathrm{Pr032754291}$ & $\begin{array}{l}\text { Between exons } 2 \\
\text { and } 3\end{array}$ & GT & $\begin{array}{l}\text { F: 5'-TAATCAGAGTGTCCTGGCATGTTCT-3' } \\
\text { R: 5'-CTTTCAGCTGTGCAGATGACTGTG-3' }\end{array}$ & 118 & HEX \\
\hline & $\mathrm{S} 2=\operatorname{PrO32754292}$ & $\begin{array}{l}\text { Between exons } 5 \\
\text { and } 6\end{array}$ & $A C$ & $\begin{array}{l}\text { F: 5'-GCAACAAGACTCTCAGCATCACAG-3' } \\
\text { R: 5'-ACAAATTCTCATAGTACCTGGGAACC-3' }\end{array}$ & 294 & HEX \\
\hline & S3 $=$ Pr032754293 & $\begin{array}{l}\text { Between exons } 6 \\
\text { and } 7\end{array}$ & TTA & $\begin{array}{l}\text { F: 5'-TGGGGAAGTCCAAAGTCTTTCTG-3' } \\
\text { R: 5'-GTTAACTGAGGGTTCTAGTGTCTTGAGT-3' }\end{array}$ & 326 & HEX \\
\hline
\end{tabular}

The size of the fragments are presented according to the mentioned accession numbers. Forward primers were labeled with the FAM or HEX fluorophores.

OCA6 (OMIM:113750) occurs due to mutations in SLC24A5 that has a role in skin pigmentation. ${ }^{16,17}$ The SLC24A5 protein belongs to a family of potassium-dependent sodium/calcium exchangers. ${ }^{18}$

Mutations in C10ORF11 result in OCA7 (OMIM:615179). The protein encoded by this gene is an LRRs (leucine-rich repeats) containing protein and may be involved in cell adhesion and signaling, extracellular-matrix assembly, platelet aggregation, neuronal development, RNA processing and immune response. ${ }^{15}$

Eye findings in Ocular albinism (OA) and OCA patients are similar, but the hair and skin are not affected in OA. ${ }^{19}$ Both X-linked recessive (OA1) and autosomal recessive (AROA) forms of OA are reported. ${ }^{20}$ The latter may be a clinically mild form of OCA, due to mutations in either the TYR or OCA2 genes. $^{21}$

Because of the observed range of phenotypic variation in albinism patients, genetic analysis may be helpful with respect to a more accurate diagnosis and genetic counseling. ${ }^{2,22}$

Mutations that are detected by molecular genetics methods can be analyzed in silico to determine their effects. Several in silico mutation analysis of OCA genes are reported such as mutational analysis of TYR gene and its protein structural or functional consequences, ${ }^{23,24}$ Bioinformatic analysis of mutations in TYRP1 gene $\mathrm{e}^{25,26}$ and computational screening of mutations in OCA2 gane. ${ }^{27}$

In this study, we performed homozygosity mapping using STR markers in order to pinpoint the genes involved and to find the mutations in the families with consanguineous marriage.

\section{MATERIALS AND METHODS}

Twenty three unrelated Iranian albinism patients, including 2 AROA and 21 nonsyndromic OCA patients from unrelated families were recruited in this study. All of them were previously screened for TYR gene mutations. ${ }^{28}$ The study was approved by the local ethics committee and the informed written consent was obtained from all patients and their parents.

Genomic DNA was extracted from peripheral whole blood of the patients and their parents using salting out method.

Tandem repeats were selected inside the TYR, OCA2, TYRP1, SLC45A2 (MATP), SLC24A5 and C10ORF11 genes using TRF (https://tandem.bu.edu/trf/ trf.html ${ }^{29}$ and SERV (http://www.igs.cnrs-mrs.fr/SERV/) ${ }^{30}$ programs. These STR markers were later submitted to the Probe database (http://www.ncbi.nlm. nih.gov/probe) and registered with the probe accession numbers presented in Table 1. Thirteen primer pairs were designed and fluorescently labeled to amplify these STR markers (Table 1).

The STR markers in the patients, their parents and siblings (if available) were amplified performing two multiplex PCR. The fragments were separated on 3130 Genetic Analyzer (Foster City, CA, USA) using 500 ROX size standard and the data were analyzed by GeneMarker software (State College, PA, USA). Homozygous loci in each family were selected for further studies by PCR and cycle sequencing. The primers were designed for all exons and intron-exon boundaries of screened genes using gene runner software and primer blast website http://www.ncbi.nlm.nih.gov/tools/primer-blast/ (Supplementary Table 1). Novel mutations were analyzed using tools such as SIFT, PolyPhen and MutationTaster and were interpreted based on ACMG (American College of Medical Genetics) standards and guideline. ${ }^{31}$ Their pathogenicity was confirmed by ascertaining co-segregation in the families and by screening a panel of population-matched healthy controls.

\section{RESULTS}

In this study, we performed mutation analysis of the nonsyndromic OCA genes in 23 unrelated albinism patients (2 AROA and 21 OCA patients) in families with consanguineous marriage. All patients were studied for TYR mutations previously. ${ }^{28} 14$ out of 23 patients 

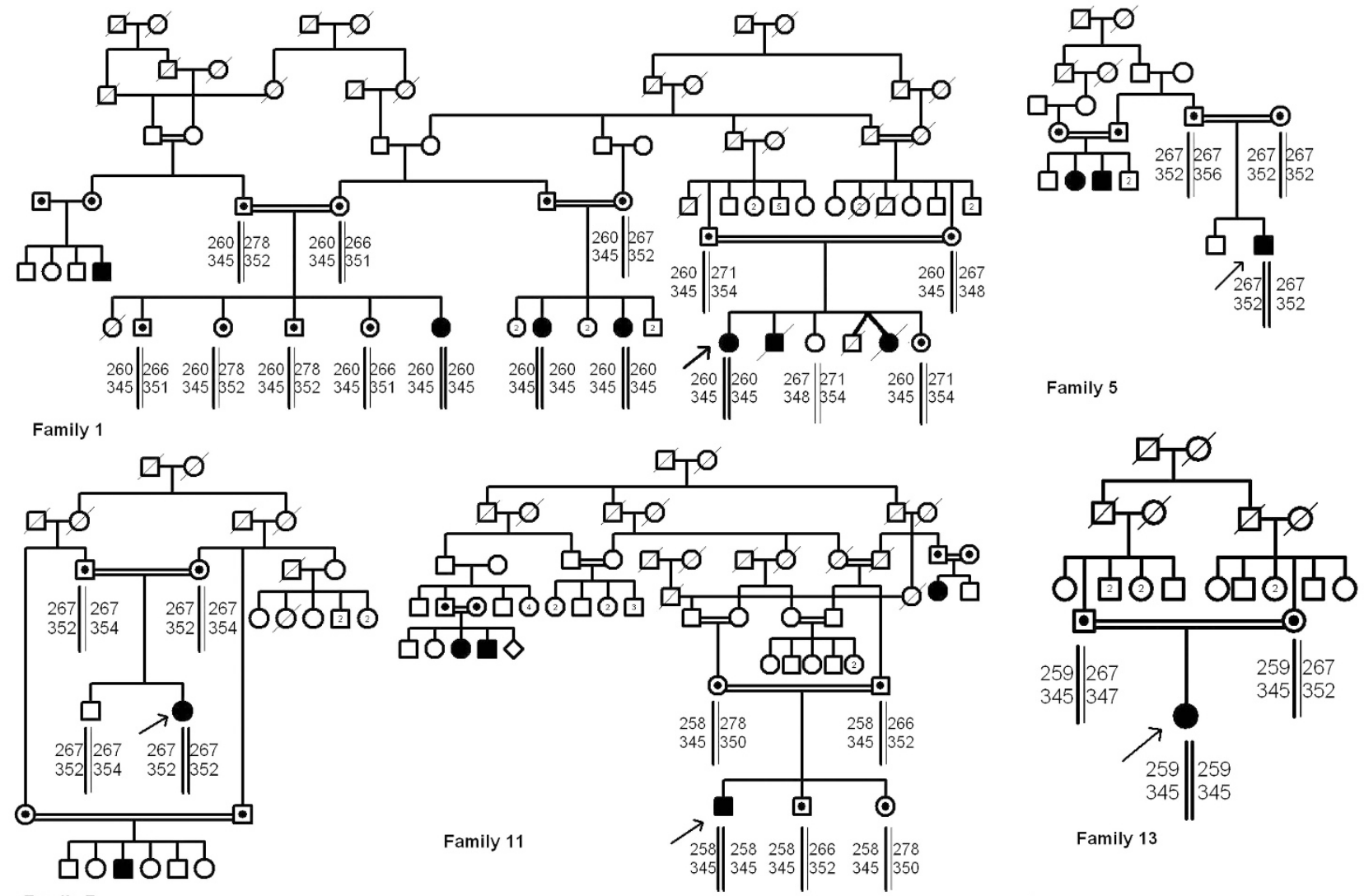

Family 7
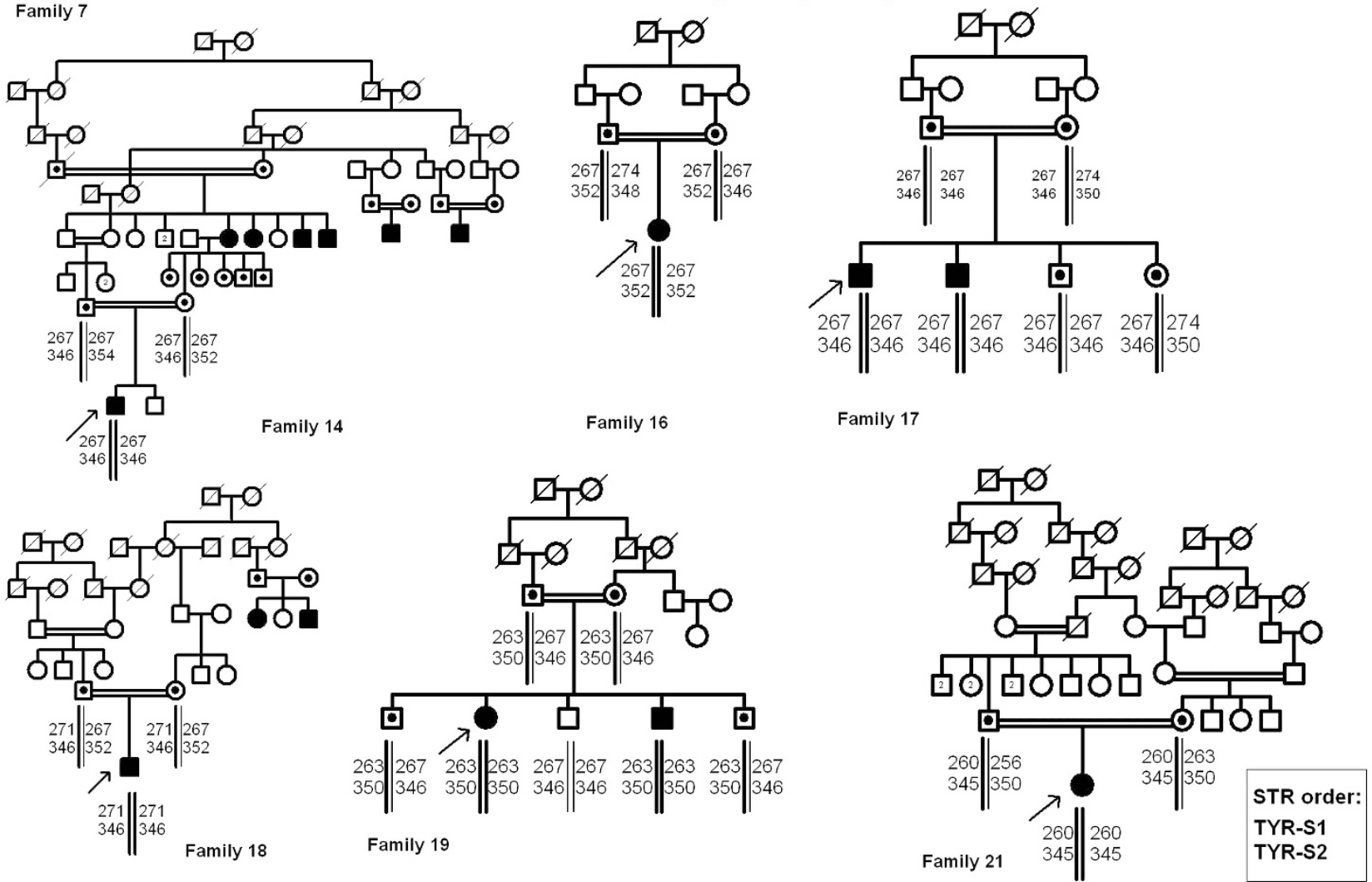

Figure 1 Families with homozygous mutations in TYR gene. Only the sizes of the STRs inside the TYR gene are displayed. 
a

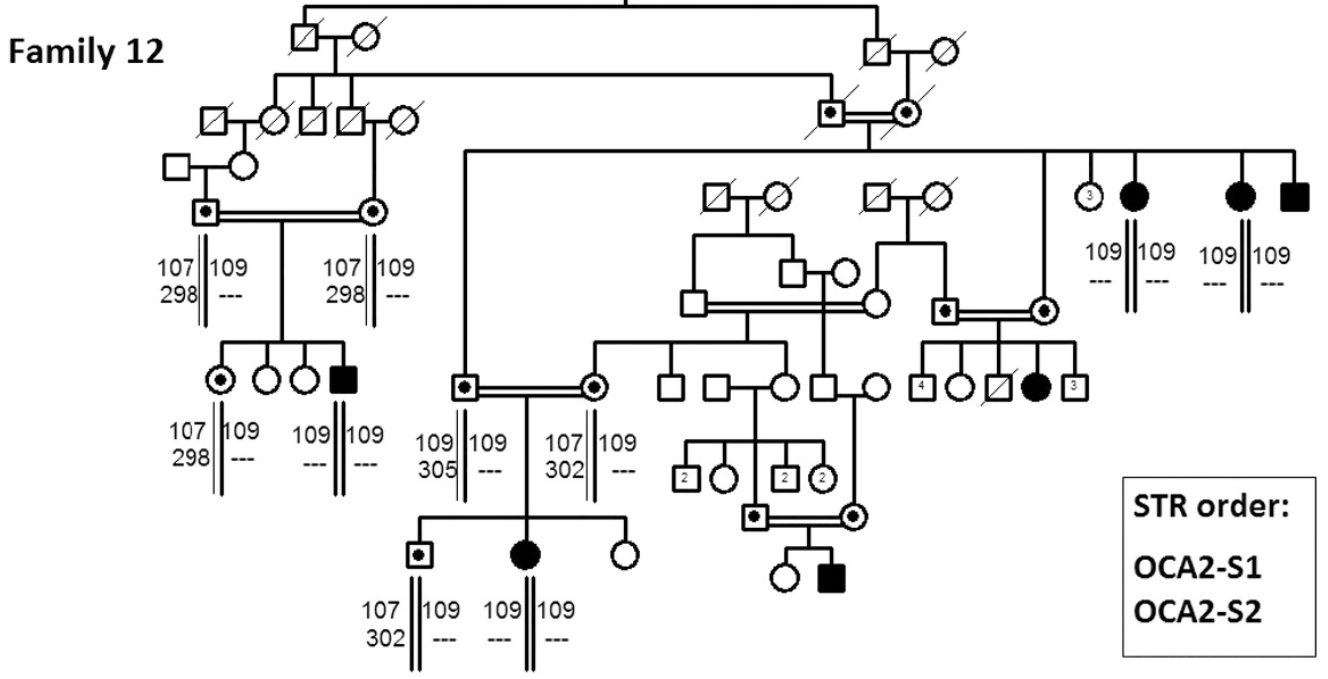

b
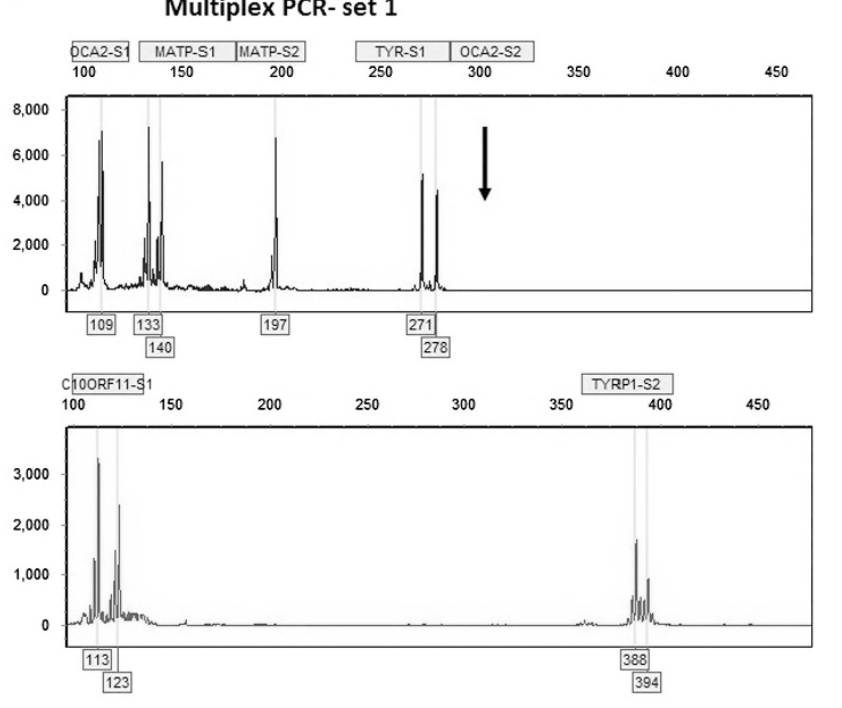

C

Multiplex PCR- set 2
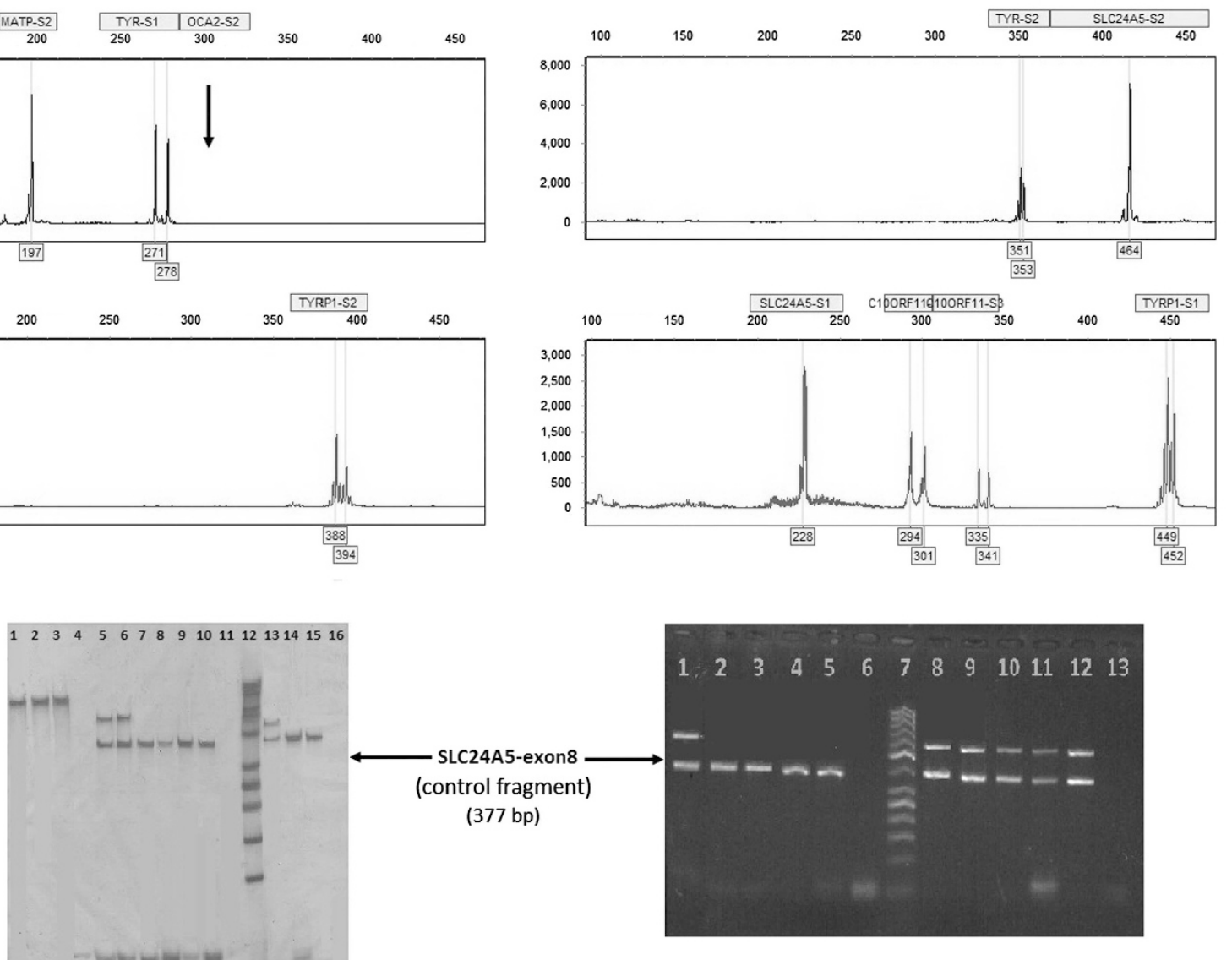

Figure 2 Family 12 with the deletion of exons 3-18 of the OCA2 gene. (a) The pedigree and the results of the homozygosity mapping. All patients had homozygous allele of OCA2-S1 (109 bp) and homozygous deletion of OCA2-S2. (b) The electrophoregram data of a patient on the 3130 Genetic Analyzer. The arrow shows the deletion of the OCA2-S2. (c) Left, PCR products of the exon 2 (701 bp) in the healthy person (1), the patients (2 and 3) and blank (4), exon 3 (534 bp) in the healthy people (5 and 6), the patients (7-10) and blank (11), 50 bp size marker (12), exon 9 (489 bp) in healthy person (13), the patients (14 and 15) and the blank (16). Right, PCR products of the exon 18 (575 bp) in healthy person (1), the patients (2-5) and the blank (6), 50 bp size marker (7), and the exon 19 (572 bp) in the healthy person (8), the patients (9-12) and the blank (13). Exon 8 of SLC24A5 (377 bp) was used as an internal control for exons 3,9,18 and 19. A full color version of this figure is available at the Journal of Human Genetics journal online. 

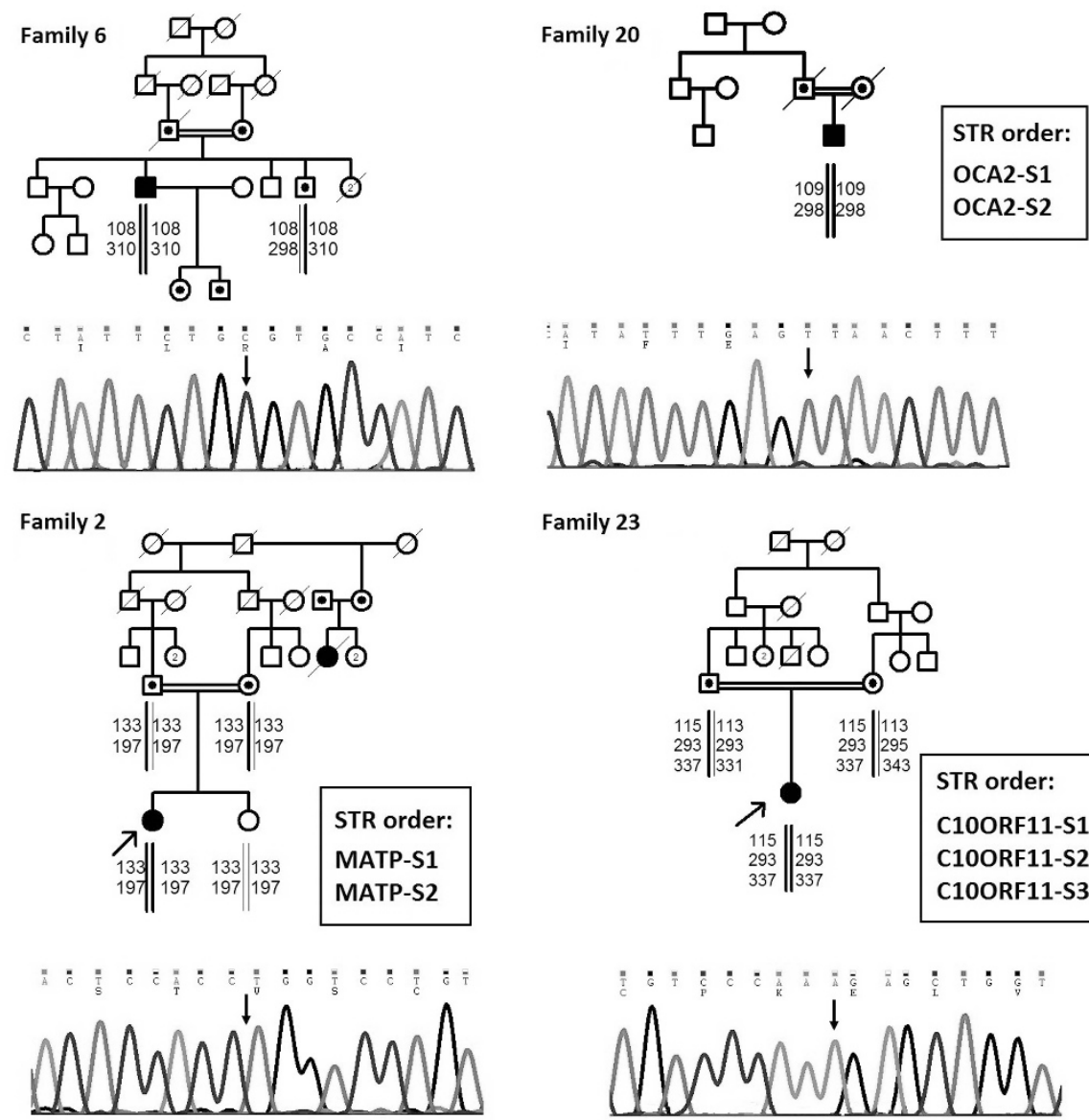

Figure 3 Family 6 with p.G657R in OCA2 gene, family 20 with IVS9+1G > T in OCA2 gene, family 2 with c.1273delC in SLC45A2 (MATP) gene and family 23 with p.N89K in C100RF11. A full color version of this figure is available at the Journal of Human Genetics journal online.

were recognized to have mutations in TYR gene, from which 11 were homozygous, 2 were compound heterozygous and 1 had only one mutation (p.P406L). For nine remaining patients no mutation was found.

Using fluorescently labeled primers to amplify STR markers existing inside the six OCA genes, all families were first screened for the homozygous loci in the patient, and then the screened loci in each family were sequenced. In addition to confirming our findings on TYR gene (Figure 1), we found five novel mutations in homozygous form, including three mutations in OCA2 (p.G657R, Del exons 3-18 and IVS9 $+1 \mathrm{G}>\mathrm{T}$ in patients 6,12 and 20 , respectively), one mutation in SLC45A2 gene (c.1273delC in patient 2) and one mutation in C10ORF11 (p.N89K in patient 23) (Figures 2,3 and Table 2).

The mutations co-segregated in the families and did not exist in the 50 healthy controls.

\section{DISCUSSION}

Due to the consanguineous marriage in Iran (with the overall rate of about $38.6 \%),{ }^{32,33}$ the probability of the genetic disorders due to common ancestors is increased.

To our knowledge, it is the first comprehensive genetic analysis of the OCA patients in which all six nonsyndromic OCA genes are studied by homozygosity mapping using STR markers inside the relevant genes. Although this approach has been used and for the diagnosis of genetically heterogeneous disorders such as genodermatoses and ichtiosis. ${ }^{34,35}$
In some families (such as families 2 and 17), some STR markers were semi-informative or not informative. However, we sequenced all the genes that showed homozygous pattern for STR markers in those families irrespective of being genuinely informative with respect to being disease causing or not.

Five mutations were found in this study, all of which were novel. Three patients had mutations in OCA2 gene. Patient 6 had p.G657R mutation, which is a missense variant in one of the transmembrane domains of OCA2 protein. Tools such as SIFT, Polyphen-2 and MutationTaster, predict p.G657R as a disease causing mutation. According to the ACMG standards and guidelines for interpretation of sequence variants, this novel mutation is likely pathogenic.

Deletion of exons 3-18 of OCA2 gene was observed in patients of pedigree 12 that is one of the biggest pedigrees we studied. Gross deletions in OCA2 have been reported ${ }^{36-39}$ and the largest reported deletion covered the entire gene. ${ }^{40}$

Patient 20 had IVS9+1G $>$ T in his OCA2 gene. Human splicing finder tool predicted that the wild type donor site is broken, so intron retention probably occurs. According to the ACMG standards and guidelines these two latter variants are pathogenic.

Patient 2 who was heterozygous for p.P406L in TYR gene, had also c.1273delC (p.Leu425Trpfs) in her SLC45A2 gene in homozygous form. This mutation is a frameshifting one and causes a termination signal in ninth codon after. Although patients with digenic OCA who have mutations in TYR and SLC45A2 genes are reported, ${ }^{5}$ the mother of this patient (heterozygous for p.P406L mutation in TYR and 
Table 2 Mutations in 23 albinism patients and the clinical and molecular diagnosis of OCA

\begin{tabular}{|c|c|c|c|c|c|}
\hline Pedigree & $\begin{array}{c}\text { Clinical } \\
\text { diagnosis }\end{array}$ & $\begin{array}{c}\text { Loci screened } \\
\text { by homozygosity } \\
\text { mapping }\end{array}$ & $\begin{array}{c}\text { Homozygous } \\
\text { mutations }\end{array}$ & $\begin{array}{l}\text { Molecular } \\
\text { diagnosis }\end{array}$ & $\begin{array}{c}\text { Heterozygous } \\
\text { mutations in } \\
\text { TYR gene }\end{array}$ \\
\hline 1 & OCA & TYR & c.286dupA & OCA1A & \\
\hline 2 & OCA & $\begin{array}{l}\text { SLC24A5 } \\
\text { MATP }\end{array}$ & $\begin{array}{c}\text { No mutation } \\
\text { c.1273delC } \\
\text { (p.Leu425Trpfs) }\end{array}$ & OCA4 & p.P406L \\
\hline 3 & AROA & $\begin{array}{l}\text { SLC24A5 } \\
\text { OCA2 }\end{array}$ & $\begin{array}{l}\text { No mutation } \\
\text { No mutation }\end{array}$ & ND & \\
\hline 4 & OCA & SLC24A5 & No mutation & ND & \\
\hline 5 & OCA & TYR & p.M332I & OCA1B & \\
\hline 6 & OCA & OCA2 & $\begin{array}{c}\text { p.G657R } \\
\text { (c.1969G >C) }\end{array}$ & OCA2 & \\
\hline 7 & OCA & $T Y R$ & p.M332। & OCA1B & \\
\hline 8 & OCA & $\begin{array}{c}\text { TYR } \\
\text { MATP } \\
\text { C10ORF11 }\end{array}$ & $\begin{array}{l}\text { No mutation } \\
\text { No mutation } \\
\text { No mutation }\end{array}$ & ND & \\
\hline 9 & OCA & - & - & OCA 1 & $\begin{array}{c}\text { p.R239W and } \\
\text { p.M332I }\end{array}$ \\
\hline 10 & OCA & - & - & ND & \\
\hline 11 & OCA & TYR & c.286dupA & OCA1A & \\
\hline 12 & OCA & OCA2 & Del exons 3-18 & OCA2 & \\
\hline 13 & OCA & $T Y R$ & c.286dupA & OCA1A & \\
\hline 14 & OCA & $T Y R$ & p.R77Q & OCA1A & \\
\hline 15 & OCA & - & - & OCA1A & $\begin{array}{c}\text { p.G47S and } \\
\text { c.del1276-82 }\end{array}$ \\
\hline 16 & OCA & $T Y R$ & p.P21S & OCA1A & \\
\hline 17 & OCA & $T Y R$ & p.R77Q & OCA1A & \\
\hline 18 & OCA & $\begin{array}{c}\text { TYR } \\
\text { C100RF11 }\end{array}$ & $\begin{array}{c}\text { p.G419R } \\
\text { No mutation }\end{array}$ & OCA1A & \\
\hline 19 & OCA & $T Y R$ & p.P301L & OCA1A & \\
\hline 20 & OCA & $\begin{array}{l}\text { SLC24A5 } \\
\text { OCA2 }\end{array}$ & $\begin{array}{c}\text { No mutation } \\
\text { IVS9+1G>T } \\
(\text { c. } 1044+1 G>T)\end{array}$ & OCA2 & \\
\hline 21 & OCA & $T Y R$ & c.286dupA & OCA1A & \\
\hline 22 & OCA & $S L C 24 A 5$ & No mutation & ND & \\
\hline 23 & AROA & $\begin{array}{c}\text { MATP } \\
\text { C10ORF11 }\end{array}$ & $\begin{array}{l}\text { No mutation } \\
\text { p.N89K } \\
\text { (c. } 267 \mathrm{C}>\mathrm{A})\end{array}$ & OCA7 & \\
\hline
\end{tabular}

Abbreviations: ND, not determined; OCA, oculocutaneous albinism.

Mutations in TYR gene are derived from our previous study.

c.1273delC in SLC45A2 gene) and also her father (heterozygous for p.R402Q polymorphism in TYR and c.1273delC in SLC45A2 gene) were both healthy. However, these findings do not contradict the pathogenicity of p.P406L.

Patient 23 who suffered from AROA was homozygous for p.N89K in C10ORF11 (NM_032024). This mutation occurred in the LRR4 domain of the protein. Mentioned bioinformatics tools (MutationTaster, PolyPhen-2, PROVEN and I-Mutant2) predicted p.N89K to be a disease causing mutation. According to the ACMG standards and guidelines, this novel mutation is likely pathogenic. Although functional studies are needed in order to confirm its pathogenisity. Gronskov et al. for the first time reported mutations in C10orf11 cause autosomal recessive albinism (OCA7). ${ }^{15}$ Also some cases with AROA have mutations in either the TYR or OCA2 (P) genes. ${ }^{21}$ Here for the first time, we reported a patient with AROA (which can be a mild form of OCA) who had a mutation in C10ORF11.
No mutation was found in SLC24A5 gene and none of the families showed homozygosity for in TYRP1 gene. Mutations in five patients remained unidentified. This may be due to the involvement of other genes, variants in the promoter or other regulatory elements that were not covered in this study or compound heterozygote or digenic OCA.

These STR markers can enable us to screen for the responsible genes in OCA patients in inbred families with homozygosity mapping. Also, they can be used for linkage analysis in the families with compound heterozygous patients or without consanguinity marriage. However, the increase of the markers inside or adjacent to the genes are suggested in order to ease the further analysis.

\section{CONFLICT OF INTEREST}

The authors declare no conflict of interest.

\section{ACKNOWLEDGEMENTS}

We thank the albinism families for their collaboration. The personnel of Tehran Medical Genetics Laboratory are appreciated for their help and support. This project was financially supported by Tehran Medical Genetics Laboratory, grant number 93003 .

1 Kamaraj, B. \& Purohit, R. Mutational analysis of oculocutaneous albinism: a compact review. BioMed. Res. Int. 2014, 905472 (2014).

2 Passmore, L., Kaesmann-Kellner, B. \& Weber, B. Novel and recurrent mutations in the tyrosinase gene and the $\mathrm{P}$ gene in the German albino population. Hum. Genet. 105, 200-210 (1999).

3 Gargiulo, A., Testa, F., Rossi, S., Di lorio, V., Fecarotta, S., de Berardinis, T. et al. Molecular and clinical characterization of albinism in a large cohort of Italian patients. Invest. Ophthalmol. Vis. Sci. 52, 1281 (2011).

4 Opitz, S., Käsmann-Kellner, B., Kaufmann, M., Schwinger, E. \& Zühlke, C. Detection of 53 novel DNA variations within the tyrosinase gene and accumulation of mutations in 17 patients with albinism. Hum. Mutat. 23, 630-631 (2004).

5 Wei, A., Yang, X., Lian, S. \& Li, W. Genetic analyses of Chinese patients with digenic oculocutaneous albinism. Chin. Med. J. 126, 226-230 (2013).

6 Wilk, M. A., McAllister, J. T., Cooper, R. F., Dubis, A. M., Patitucci, T. N., Summerfelt, P. et al. Relationship between foveal cone specialization and pit morphology in albinism. Invest. Ophthalmol. Vis. Sci. 55, 4186 (2014).

7 Kausar, T., Bhatti, M., Ali, M., Shaikh, R. \& Ahmed, Z. OCA5, a novel locus for non-syndromic oculocutaneous albinism, maps to chromosome 4q24. Clin. Genet. 84, 91-93 (2013).

8 Visser, M., Kayser, M., Grosveld, F. \& Palstra, R. J. Genetic variation in regulatory DNA elements: the case of OCA2 transcriptional regulation. Pigment Cell Melanoma Res. 27, 169-177 (2014).

9 Montoliu, L., Grønskov, K., Wei, A. H., Martínez-García, M., Fernández, A., Arveiler, B. et al. Increasing the complexity: new genes and new types of albinism. Pigment Cell Melanoma Res. 27, 11-18 (2014).

10 Wei, A. H. \& Li, W. Hermansky-Pudlak syndrome: pigmentary and non-pigmentary defects and their pathogenesis. Pigment Cell Melanoma Res. 26, 176-192 (2013).

11 Tomita, Y. \& Miyamura, Y. Oculocutaneous albinism and analysis of tyrosinase gene in Japanese patients. Nagoya J. Med. Sci. 61, 97-102 (1998).

12 Yuasa, I., Umetsu, K., Harihara, S., Miyoshi, A., Saitou, N., Park, K. S. et al. OCA2* 481Thr, a hypofunctional allele in pigmentation, is characteristic of northeastern Asian populations. J. Hum. Genet. 52, 690-693 (2007).

13 Jaworek, T. J., Kausar, T., Bell, S. M., Tariq, N., Maqsood, M. I., Sohail, A. et al. Molecular genetic studies and delineation of the oculocutaneous albinism phenotype in the Pakistani population. Orphanet J. Rare Dis. 7, 44 (2012).

14 Kobayashi, T., Urabe, K., Winder, A., Jimenez-Cervantes, C., Imokawa, G., Brewington, T. et al. Tyrosinase related protein 1 (TRP1) functions as a DHICA oxidase in melanin biosynthesis. EMBO J. 13, 5818- (1994).

15 Grønskov, K., Dooley, C. M., Østergaard, E., Kelsh, R. N., Hansen, L., Levesque, M. P. et al. Mutations in c10orf11, a melanocyte-differentiation gene, cause autosomalrecessive albinism. Am. J. Hum. Genet. 92, 415-421 (2013).

16 Wei, A.-H., Zang, D.-J., Zhang, Z., Liu, X.-Z., He, X., Yang, L. et al. Exome sequencing identifies SLC24A5 as a candidate gene for nonsyndromic oculocutaneous albinism. J. Invest. Dermatol. 133, 1834-1840 (2013).

17 Lamason, R. L., Mohideen, M.-A. P., Mest, J. R., Wong, A. C., Norton, H. L., Aros, M. C. et al. SLC24A5, a putative cation exchanger, affects pigmentation in zebrafish and humans. Science 310, 1782-1786 (2005).

18 Schnetkamp, P. P. The SLC24 Na+/Ca2+-K+ exchanger family: vision and beyond. Pflügers Archiv 447, 683-688 (2004).

19 Simeonov, D. R., Wang, X., Wang, C., Sergeev, Y., Dolinska, M., Bower, M. et al. DNA variations in oculocutaneous albinism: an updated mutation list and current outstanding issues in molecular diagnostics. Hum. Mutat. 34, 827-835 (2013). 
20 Fukai, K., Holmes, S. A., Lucchese, N. J., Siu, V. M., Weleber, R. G., Schnur, R. E. et al. Autosomal recessive ocular albinism associated with a functionally significant tyrosinase gene polymorphism. Nat. Genet. 9, 92-95 (1995).

21 Hutton, S. M. \& Spritz, R. A. A comprehensive genetic study of autosomal recessive ocular albinism in Caucasian patients. Invest. Ophthalmol. Vis. Sci. 49, 868 (2008).

22 Hutton, S. M. \& Spritz, R. A. Comprehensive analysis of oculocutaneous albinism among non-Hispanic caucasians shows that OCA1 is the most prevalent OCA type. J. Invest. Dermatol. 128, 2442-2450 (2008).

23 Balu, K. \& Purohit, R. Mutational analysis of TYR gene and its structural consequences in OCA1A. Gene 513, 184-195 (2013).

24 Zheng, H., Huang, Z., Wen, R. \& Li, H. Study of tyrosinase gene mutation in oculocutaneous albinism type 1 patients. Zhongguo Ying Yong Sheng Li Xue Za Zhi 27, 329-332 (2011).

25 Zhang, K.-h., Li, Z., Lei, J., Pang, T., Xu, B., Jiang, W.-y. et al. Oculocutaneous albinism type 3 (OCA3): analysis of two novel mutations in TYRP1 gene in two Chinese patients. Cell Biochem. Biophys. 61, 523-529 (2011).

26 Kamaraj, B. \& Purohit, R. In silico screening and molecular dynamics simulation of disease-associated nsSNP in TYRP1 gene and its structural consequences in OCA3. BioMed Res. Int. 2013, 697051 (2013).

27 Kamaraj, B. \& Purohit, R. Computational screening of disease-associated mutations in OCA2 gene. Cell Biochem. Biophys. 68, 97-109 (2014).

28 Khordadpoor-Deilamani, F., Akbari, M. T., Karimipoor, M. \& Javadi, G. Sequence analysis of tyrosinase gene in ocular and oculocutaneous albinism patients: introducing three novel mutations. Mol. Vis. 21, 730 (2015).

29 Benson, G. Tandem repeats finder: a program to analyze DNA sequences. Nucleic Acids Res. 27, 573 (1999).

30 Legendre, M., Pochet, N., Pak, T. \& Verstrepen, K. J. Sequence-based estimation of minisatellite and microsatellite repeat variability. Genome Res. 17, 1787-1796 (2007).

31 Richards, S., Aziz, N., Bale, S., Bick, D., Das, S., Gastier-Foster, J. et al. Standards and guidelines for the interpretation of sequence variants: a joint consensus recommendation of the American College of Medical Genetics and Genomics and the Association for Molecular Pathology. Genet. Med. 17, 405-424 (2015).

32 Saadat, M., Ansari-Lari, M. \& Farhud, D. Short Report Consanguineous marriage in Iran. Ann. Hum. Biol. 31, 263-269 (2004).

33 Akrami, S. M., Montazeri, V., Shomali, S. R., Heshmat, R. \& Larijani, B. Is there a significant trend in prevalence of consanguineous marriage in Tehran? A review of three generations. J. Genet. Couns. 18, 82-86 (2009).

34 Mizrachi-Koren, M., Shemer, S., Morgan, M., Indelman, M., Khamaysi, Z., Petronius, D. et al. Homozygosity mapping as a screening tool for the molecular diagnosis of hereditary skin diseases in consanguineous populations. J. Am. Acad. Dermatol. 55 393-401 (2006).

35 Lugassy, J., Hennies, H. C., Indelman, M., Khamaysi, Z., Bergman, R. \& Sprecher, E. Rapid detection of homozygous mutations in congenital recessive ichthyosis. Arch. Dermatol. Res. 300, 81-85 (2008).

36 Claas, M., Timmermans, A. \& Bruinse, H. Case report: a black and white twin. J. Perinatol. 30, 434-436 (2010).

37 Rooryck, C., Morice-Picard, F., Elçioglu, N. H., Lacombe, D., Taieb, A. \& Arveiler, B. Molecular diagnosis of oculocutaneous albinism: new mutations in the OCA1-4 genes and practical aspects. Pigment Cell Melanoma Res. 21, 583-587 (2008).

38 Wei, A., Wang, Y., Long, Y., Wang, Y., Guo, X., Zhou, Z. et al. A comprehensive analysis reveals mutational spectra and common alleles in Chinese patients with oculocutaneous albinism. J. Invest. Dermatol. 130, 716-724 (2010).

39 Yi, Z., Cohen-Barak, O., Karafet, T. M., King, R. A., Erickson, R. P., Hammer, M. F. et al. A 122.5-kilobase deletion of the $\mathrm{P}$ gene underlies the high prevalence of oculocutaneous albinism type 2 in the Navajo population. Am. J. Hum. Genet. 72 , 62-72 (2003)

40 Rinchik, E. M., Bultman, S. J., Horsthemke, B., Lee, S.-T., Strunk, K. M., Spritz, R. A. et al. A gene for the mouse pink-eyed dilution locus and for human type II oculocutaneous albinism. Nature 361, 72-76 (1993).

Supplementary Information accompanies the paper on Journal of Human Genetics website (http://www.nature.com/jhg) 